\title{
Platinum-group elements in sills of the Jurassic Ferrar Large Igneous Province from Northern Victoria Land, Antarctica
}

\author{
R. Hanemann and L. Viereck-Goette \\ Institut fuer Geowissenschaften, Friedrich-Schiller-Universitaet, Burgweg 11, D-07749 Jena, Germany (ricarda.hanemann@uni-jena.de)
}

\begin{abstract}
Platinum-group element (PGE) abundances were analysed in basaltic andesites and andesites from sills of the Ferrar Large Igneous Province in northern Victoria Land. The strongly fractionated primitive mantle-normalised PGEpatterns show enrichment of the Pt-PGE over the Ir-PGE. The single element abundances exhibit good correlations with the degree of differentiation of the distinctly evolved samples and are interpreted to result mainly from low-pressure insitu differentiation after magma emplacement in the upper crust. Compared to tholeiitic rocks from other magmatic provinces, only the Ferrar rocks exhibit coupled enrichment of $\mathrm{Pd}, \mathrm{Pt}$ and $\mathrm{Cu}$ even in most evolved samples. The decrease of Pt and Pd in some of the more evolved samples does not necessarily signify sulphide fractionation, but may indicate the formation of other PGE-compounds. The inferred sulphur-undersaturated conditions during differentiation are in agreement with the high degrees of partial melting as well as the refractory nature of the proposed subcontinental lithospheric mantle source beneath this magmatic province.
\end{abstract}

Citation: Hanemann, R. and L. Viereck-Goette (2007), Platinum-Group Elements in Sills of the Jurassic Ferrar Large Igneous Province from northern Victoria Land, Antarctica, in Antarctica: A Keystone in a Changing World - Online Proceedings of the 10th ISAES, edited by A. K. Cooper and C. R. Raymond et al., USGS Open-File Report 2007-1047, Short Research Paper 032, 5 p.; doi:10.3133/of2007-1047.srp032

\section{Introduction}

Basaltic andesites of the Jurassic Ferrar Large Igneous Province, exposed in a linear belt along the Palaeo-Pacific margin of Gondwana, comprise numerous sills, dikes and lava flow sequences as well as the Dufek layered mafic intrusion. Uniform crust-like trace element and isotope data indicate an identical magma source for both the lowand high-Ti rocks of the $>3000$-km long Ferrar magmatic province. A subcontinental lithospheric mantle source has been proposed for the Ferrar rocks, characterised by crustal enrichment due to Palaeozoic subduction along the cratonic margin of Gondwana (e.g., Hergt et al., 1989). However, the thermal source for the voluminous melt generation is still under debate as the crust-like isotope data obscure the detection of a possible mantle plume involvement.

Our ongoing petrogenetic studies intend to further describe the genesis of the Ferrar magmas. In addition to mineral and bulk-rock chemical data for tholeiitic rocks from Ferrar sills in northern Victoria Land, a subset of 23 samples has so far been analysed for the platinum-group elements (PGE). The abundances of Ir, Ru, Rh, Pt and Pd were determined by ICP-MS using isotope dilution (except Rh) after concentration and separation of the PGE by NiS-fire assay at the University of Karlsruhe, Germany. The selected samples comprise the entire petrographic and geochemical variations observed.

\section{Previous results}

The basaltic andesites and andesites exhibit the common phase assemblage of tholeiitic differentiation sequences composed of varying amounts of pyroxenes, plagioclase, oxides and mesostasis. All samples have been categorised as low-Ti (LTS: $\mathrm{TiO}_{2} \sim 0.4-1.2 \mathrm{wt} \%$ ) and high-Ti series (HTS: $\mathrm{TiO}_{2} \sim 1.7-2.1 \mathrm{wt} \%$ ). Compared to the LTS, rocks of the HTS exhibit higher concentrations of $\mathrm{FeO}, \mathrm{TiO}_{2}$ and incompatible trace elements (incl. REE) at comparable $\mathrm{SiO}_{2}$. Chilled margins of the low-Ti sills $(\mathrm{MgO} \sim 7 \mathrm{wt} \%)$ reflect the pre-intrusive composition of the low-Ti magmas, from which cumulates and differentiates $(\mathrm{MgO} \sim 12-3 \mathrm{wt} \%)$ developed by lowpressure in-situ differentiation after magma intrusion at near-surface levels. Our mineral and bulk-rock chemical results further indicate that the magmas of the chemically more evolved but uniform HTS ( $\mathrm{MgO} \sim 3-2 \mathrm{wt} \%)$ are not generated by continued low-pressure fractionation of the LTS magmas. Assuming an identical primary magma for both series, different conditions during pre-emplacement differentiation are proposed to explain the two distinct compositions.

\section{Results of PGE analysis}

The PGE concentrations range from $\sim 4$ to 40 parts per billion (ppb) with systematic variations of the individual PGE, as illustrated on the diagrams in figure 1 against $\mathrm{MgO}$ which is used as a differentiation index. For all samples, Ir behaves compatibly with abundances near the limit of detection $(0.1 \mathrm{ppb})$ in the most evolved rocks. $\mathrm{Ru}$ and $\mathrm{Rh}$ are rather invariant in low-Ti rocks. In high-Ti rocks, $\mathrm{Ru}$ is below the detection limit. Pt and Pd show bimodal variations in the low-Ti sills. Relative to the chilled margins, these two elements decrease in cumulates $(\mathrm{MgO}>7 \mathrm{wt} \%)$, but either increase or decrease in differentiates $(\mathrm{MgO}<7 \mathrm{wt} \%)$. In the compositionally uniform high-Ti rocks, $\mathrm{Rh}, \mathrm{Pt}$ and $\mathrm{Pd}$ are highly variable and exhibit generally higher abundances than low-Ti rocks (except of one high-Ti sample). All rocks show strongly fractionated primitive mantle-normalised patterns with increasing normalised values from Ir to Pd, which reflect considerable enrichment of the PPGE (Rh, Pt, Pd) over the IPGE (Ir, Ru).

\section{Discussion}

The fractionation of the IPGE from the PPGE for all present Ferrar samples may, to a certain extent, result 
from melt generation and reflect a primary feature of their magma source. However, as most of the wide bulk-rock chemical variations of the variably evolved rocks are ascribed to pre- and post-emplacement differentiation, the variations of the individual $\mathrm{PGE}$ with $\mathrm{MgO}$ are also attributed to differentiation processes as discussed in detail below.
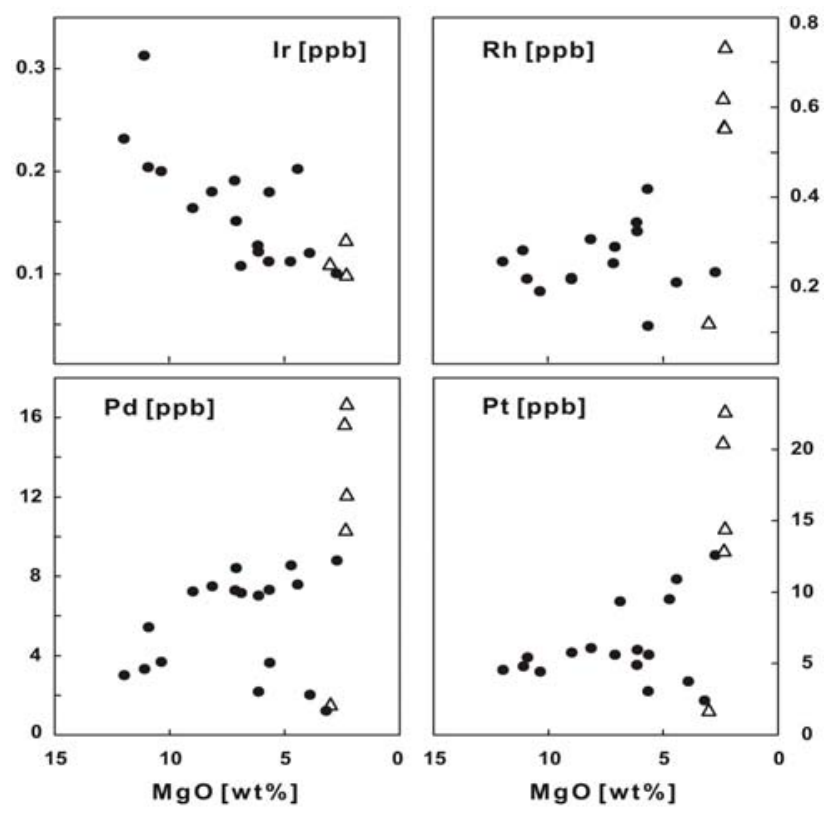

Figure 1. Variations of individual $\mathrm{PGE}$ with $\mathrm{MgO}$ as measure of differentiation of the Ferrar low-Ti $(\bullet)$ and high-Ti $(\Delta)$ rocks from northern Victoria Land.

\section{Post-emplacement magma evolution}

After upper crustal magma emplacement, the initial $\mathrm{Pd} / \mathrm{Ir}$ ratio of $\sim 55$ for the low-Ti chilled margins changed by in-situ differentiation to 10 for accumulated and to 87 for differentiated low-Ti rocks. Despite their strikingly homogeneous composition, the few high-Ti rocks exhibit a very wide range of $\mathrm{Pd} / \mathrm{Ir}$ ratios from 14 to 167 . These variations reflect the steadily compatible behaviour of Ir and the bimodal, predominantly incompatible behaviour of Pd (representing the PPGE, see figure 1) during lowpressure in-situ fractionation.

The unsystematic $\mathrm{Ru}$ and $\mathrm{Rh}$ variations with $\mathrm{MgO}$ in low-Ti rocks may either be attributed to their very low concentrations near the limit of detection or indicate bulkpartition coefficients close to unity.

The Ir increase in cumulates relative to the chilled margins of low-Ti sills suggests that Ir was either incorporated into a fractionating early-formed phase or was trapped by small amounts of liquid between the solidifying silicates. However, it is difficult to determine whether Ir formed highly insoluble metal alloys or monosulphide solid solutions (Bockrath et al., 2004) that were incorporated into some early-segregated silicates or oxides or was partitioned by true solid solution into the accumulated phases. With enrichment of Ir in cumulates, differentiates are left with low abundances, in some cases even below the limit of detection.

In contrast to Ir, the PPGE exhibit a complex, bimodal fractionation behaviour. Due to their high sulphide/ silicate melt partition coefficients $\left(\mathrm{k}_{\mathrm{D}}=10^{3}-10^{6}\right.$, Barnes and Maier, 1999 and references therein), the basically siderophile PGE exhibit a strong chalcophile affinity as well. Thus, it is widely accepted that sulphide fractionation is the main factor controlling PGE distribution patterns in silicate magmas. The PGE are concentrated in immiscible sulphide liquids in the order of their different $\mathrm{k}_{\mathrm{D}}$ and are fractionated from the residual silicate liquid when sulphur-saturation is reached. The PGE-bearing sulphide liquids either form immiscible droplets that are disseminated in the crystallising matrix silicates, oxides or in the mesostasis or discrete noble metal minerals fractionating from the evolving magma by segregation.

Hence, variations of PPGE are often compared with those of other chalcophile elements such as $\mathrm{Cu}$. For all Ferrar samples analysed, the negative correlation of $\mathrm{Cu}$ with a differentiation index such as $\mathrm{MgO}$ (Figure 3) indicates its incompatibility and thus S-undersaturated conditions during in-situ differentiation. However, in some of the evolved low-Ti rocks and one high-Ti rock, the PPGE are compatible and thus decoupled from $\mathrm{Cu}$ despite the inferred S-undersaturation. This is more clearly displayed by $\mathrm{Cu} / \mathrm{PPGE}$ ratios (Figure 2), which are considered constant during fractionation of silicates as long as no immiscible sulphide liquid is segregated. The almost constant $\mathrm{Cu} / \mathrm{PPGE}$ ratios with varying $\mathrm{MgO}$ of most samples confirm the mainly S-undersaturated nature of the Ferrar magmas. The partly elevated $\mathrm{Cu} / \mathrm{PPGE}$ ratios, however, indicate removal of the PPGE from the residual liquid. These may reflect a sudden increase in Ssaturation in distinct sections of the in-situ differentiated magmas that is large enough to at least fractionate the PPGE but not $\mathrm{Cu}$. It is noteworthy that this feature is shown by both magma series, but is more pronounced within the high-Ti series.

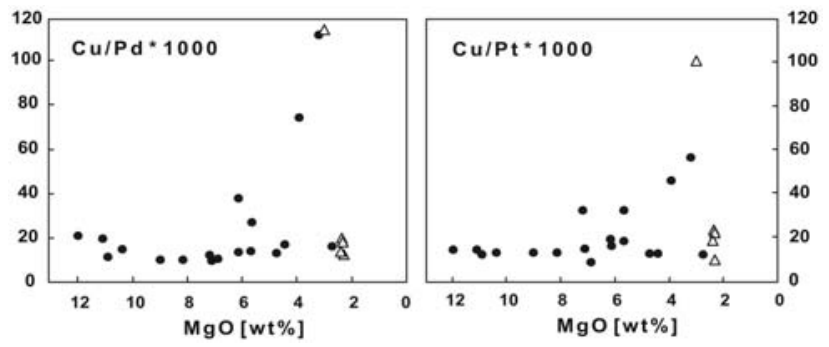

Figure 2. Variations of $\mathrm{Cu} / \mathrm{Pd}$ and $\mathrm{Cu} / \mathrm{Pt}$ ratios with $\mathrm{MgO}$ for the Ferrar low-Ti $(\bullet)$ and high-Ti $(\Delta)$ rocks.

To constrain the petrogenetic significance of the distinct PPGE behaviour in the analysed Ferrar rocks, data presented here are compared with published data for tholeiitic rocks from mid-ocean ridges (MORB) as well as seaward dipping reflector sequences (SDRS) and plateau basalts from LIPs (Figure 3). 


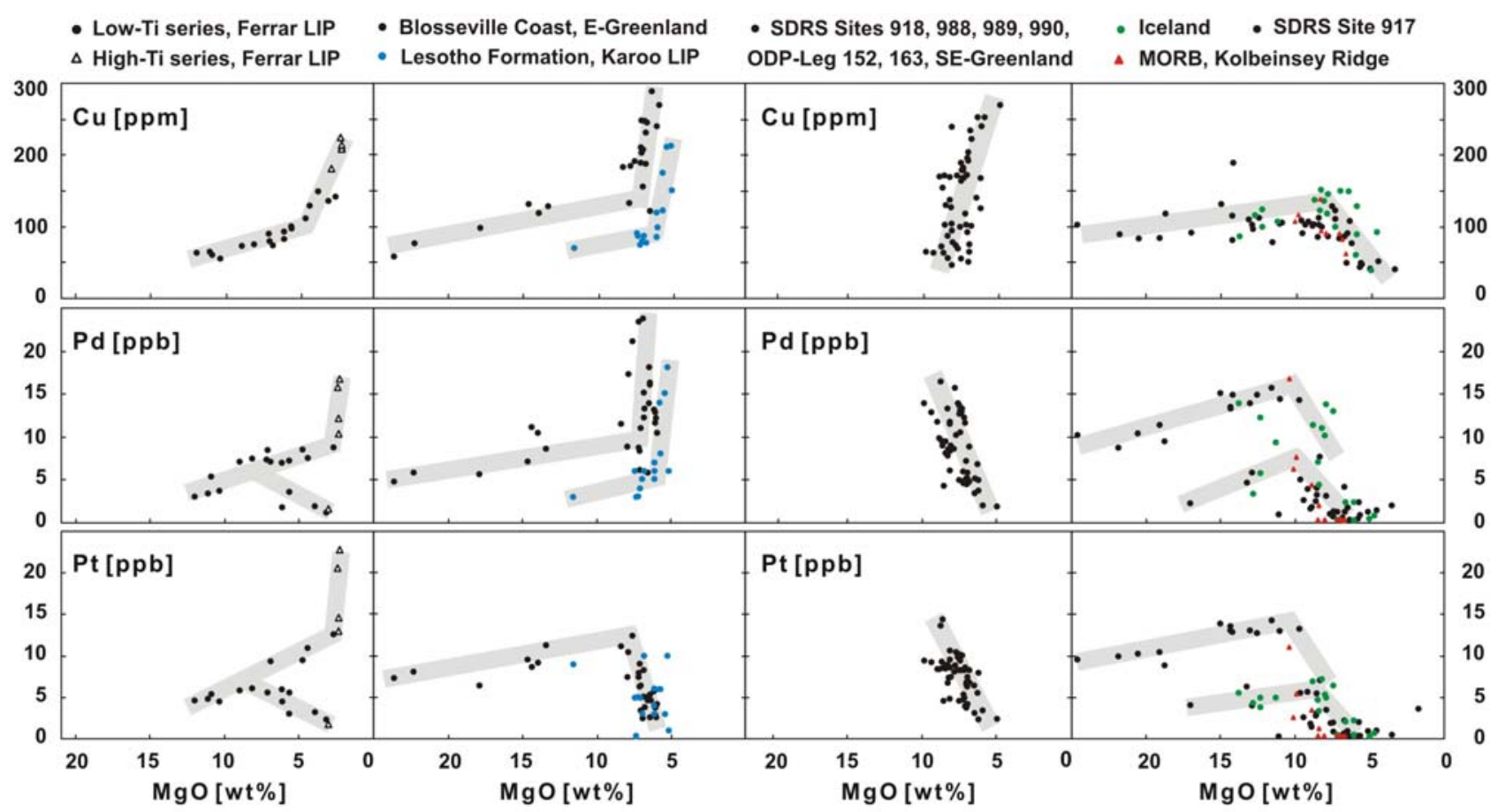

Figure 3. Variations of $\mathrm{Cu}, \mathrm{Pd}$ and $\mathrm{Pt}$ with $\mathrm{MgO}$ for tholeiitic rocks from different magmatic settings emphasising the unique combination of variation trends of these elements for rocks of the Ferrar LIP. Published data: Rehkaemper et al. (1999), Philipp et al. (2001), Andersen et al. (2002), Momme et al. (2002, 2003) and Maier et al. (2003).

All data records are nearly uniform between 25 and 10 wt $\% \mathrm{MgO}$, showing increasing $\mathrm{Cu}, \mathrm{Pd}$ and $\mathrm{Pt}$ concentrations with decreasing $\mathrm{MgO}$. Considering the high sulphide/silicate melt partition coefficients of $\mathrm{Cu}\left(10^{2}\right.$ $\left.10^{3}\right)$, and $\mathrm{Pd}$ and $\mathrm{Pt}\left(10^{3}-10^{5}\right)$ (Barnes and Maier, 1999), this increase indicates their incompatibility due to Sundersaturation during olivine fractionation of primitive picritic magmas.

The variable fractionation trends of $\mathrm{Cu}, \mathrm{Pd}$ and $\mathrm{Pt}$ below $\mathrm{MgO} \sim 10 \mathrm{wt} \%$ for the individual magma provinces can be explained by different degrees of Ssaturation achieved at distinct stages of the advancing differentiation. With respect to their S-saturation, the most contrary tholeiitic magmas are the Ferrar rocks analysed and the MOR basalts. The asthenospheric NMORB melts from the NE Atlantic and the plume-related magmas of the Iceland Neovolcanic Zone were Ssaturated enough to fractionate $\mathrm{Cu}$ at $\mathrm{MgO} \sim 7-8 \mathrm{wt} \%$, whereas the S-saturation of some Ferrar rocks was too low to fractionate any of these chalcophile elements

From the different types of variation trends, it is evident that the PPGE are fractionated earlier than $\mathrm{Cu}$, confirming that $\mathrm{Cu}$ has a lower $\mathrm{k}_{\mathrm{D}}$ for sulphides, and that Pt fractionates earlier than Pd. Assuming that this fractionation is governed mainly by the degree of Ssaturation of the evolving magma, decreasing $\mathrm{k}_{\mathrm{D}}$ values in the order $\mathrm{Pt}>\mathrm{Pd}>\mathrm{Cu}$ are suggested. This agrees with empirically estimated $\mathrm{k}_{\mathrm{D}}$ values (e.g., Philipp et al., 2001), but is inconsistent with some experimental determinations (e.g., Fleet et al., 1999) denoting higher $\mathrm{k}_{\mathrm{D}}$ 's for Pd than for Pt and hence a stronger affinity of Pd for sulphides.
This may give evidence that the fractionation of the PPGE was not only controlled by sulphides, but possibly by other phases such as metal alloys. Based on distinctly different partition coefficients reported for $\mathrm{Pd}$ and $\mathrm{Pt}$ between alloys and sulphides $\left(\mathrm{k}_{\mathrm{D}}^{\text {alloy/sulphide }} \sim 1-2\right.$ for Pd and $>10^{3}$ for Pt, Fleet and Stone, 1991), it has been recognised that $\mathrm{Pt}$ is enriched in alloy phases whereas $\mathrm{Pd}$ is preferentially concentrated into sulphides. These considerations indicate that the partitioning of PPGE in either sulphides or alloys could likely result in fractionation between Pt and Pd during in-situ differentiation of the Ferrar magmas, as displayed by the variation patterns of the continental flood basalts from East Greenland (Momme et al., 2002) or the Karoo LIP (Maier et al., 2003). Instead, the PPGE exhibit consistent fractionation behaviour for the analysed Ferrar rocks. Hence, unless any combination of fractionating sulphides and alloys is assumed for the individual PPGE during the Ferrar magma evolution, other phases besides sulphides and alloys have to be considered as well.

Sulphur is complemented by other oxy-anions available to form discrete platinum group minerals (PGM) such as arsenides, antimonides, bismuthides or tellurides in various tholeiitic rock suites. However, the origin of such PGM remains controversial. Some findings indicate that these PGM are primary mineral phases. Others are ascribed to secondary PPGE redistribution from primary magmatic sulphides according to the recognition that the PGE, in spite of their chemical inertness, are mobile under hydrothermal conditions (e.g., Wood, 2002 and references therein). However, since distinct mobilities 
have been recognised for individual PPGE (e.g., Oberthuer et al., 2003), the coupled decrease of PPGE reported here disagrees with post-magmatic modification of the initial PGE abundance patterns. Moreover, the coupled decrease of PPGE and $\mathrm{MgO}$ most likely is a primary igneous signature.

Consequently, the PPGE semi-compatibility is attributed to in-situ differentiation within the sheet-like magma reservoirs. During advanced stages of cooling and solidification, the PPGE are partly extracted from the residual silicate liquid by a fractionating phase(s) or the trapped melt between them and are thus enriched or depleted in different horizons of these magmatic bodies. However, no attempts have been made to identify the fractionating PGE phases so far. For this purpose, three massive intrusive Ferrar units will be studied in an ongoing project.

\section{Pre-emplacement magma evolution}

The evolved character of the effusive or shallow-level intrusive Ferrar rocks relative to primary mantle melts is confirmed by the marked fractionation between the individual PGE, since the $\mathrm{Pd} / \mathrm{Ir}$ ratios of mantle rocks are typically much lower. Assuming that the Ferrar source was not notably IPGE-depleted, the PPGE enrichment over the IPGE indicates a differentiation phase prior to magma emplacement, during which the IPGE are extracted from the primary magma concurrently to the removal of (near-) liquidus phases and the PPGE are enriched due to S-undersaturation of the Ferrar magmas.

Alternatively, the IPGE depletion could be interpreted to reflect their distinct behaviour during melt generation considering the higher melting points of the IPGE, since they can be preferentially retained in the mantle source due to incomplete solution of sulphides or alloys at lower melting degrees (e.g., Barnes and Maier, 1999). However, due to the facts that elevated melting degrees can be deduced from REE characteristics of the samples and that Ir correlates positively with the $\mathrm{MgO}$ contents of the low- $\mathrm{Ti}$ and high-Ti samples, an early fractionation of the IPGE is preferred.

Furthermore, the inferred high degree of partial melting can partly explain the unusually low level of Ssaturation of the Ferrar magmas since sulphides can be entirely exhausted in the melting residue at high melting degrees (e.g., Rehkaemper et al., 1999). Moreover, the Sundersaturation may reflect an inherent feature of the Ferrar magma source, suggesting derivation from a Spoor mantle source evolved to that degree by previous events of melt extraction. This corresponds to the refracttory lithospheric mantle source we have accepted. However, source characteristics may generally be modified to an uncertain extent due to secondary enrichment of the lithospheric mantle during Palaeozoic subduction.

\section{Summary}

The significant PGE fractionation of Ferrar rocks agrees with their generally evolved bulk-rock composition ascribed to an extensive pre- and post-emplacement differentiation history. The observed bimodal PPGE fractionation behaviour with concurrent increase of $\mathrm{Cu}$ during in-situ differentiation can be of different origins; however, a primarily magmatic origin is favoured over sub-solidus redistribution. To better understand the fractionation behaviour of PGE during low-pressure differentiation, detailed investigations of the stratigraphic distribution of the PGE within three massive intrusive units of the Ferrar LIP (incl. the Dufek Intrusion) are in progress (in cooperation with S. Mukasa, University of Michigan, and G. Woerner, University of Goettingen). For reasonable interpretation of the bulk-rock PGE variations, this study includes the identification of the fractionating PGE- phases.

In comparison with tholeiitic rocks from other geodynamic environments as well as large igneous provinces, the combination of PGE variation trends in Ferrar rocks is unique, since they document an increase of $\mathrm{Cu}$ as well as the PPGE. The very low degree of Ssaturation indicated can be ascribed to both high degrees of partial melting and an S-depleted nature of the Ferrar magma source region.

In conclusion, the behaviour of PGE is very sensitive to varying conditions during any magmatic process. Thus, PGE definitely provide valuable tools to study specific processes during the genesis of mafic igneous rocks. However, to reveal source characteristics, the present data set for Ferrar magmatic rocks from NVL requires a careful evaluation.

Acknowledgements. The authors would like to thank the co-editor Philip Kyle as well as Sam Mukasa and Detlef Eckhardt for thoroughly reviewing this manuscript. This study was financially supported by the German Science Foundation.

\section{References}

Andersen J. C. O., M. R. Power and M. Momme (2002), Platinum Group Elements in the Palaeogene North Atlantic Igneous Province, in The Geology, Geochemistry, Mineralogy and Mineral Beneficiation of Platinum-Group Elements, edited by L. J. Cabri, pp. 637-667, Geological Society of Canadian Institute of Mining and Metallurgy and Petroleum, Spec.Vol. 54.

Barnes S.-J. and W. D. Maier (1999), The fractionation of Ni, Cu and the noble metals in silicate and sulfide liquids, in Dynamic Processes in Magmatic Ore Deposits and their application in mineral exploration, edited by R. R. Keays, C. M. Lesher, P. C. Lightfoot and C. E. G. Farrow, pp. 69-106, Geological Association of Canada, Short Course Vol. 13.

Bockrath C., C. Ballhaus and A. Holzheid (2004), Fractionation of the Platinum-Group Elements During Mantle Melting, Science, 24, 19511953.

Fleet M. E., J. H. Crocket, M. Liu and W. E. Stone (1999), Laboratory partitioning of platinum-group elements (PGE) and gold with applications to magmatic sulfide-PGE deposits, Lithos, 47, 127-142.

Fleet M. E. and W. E. Stone (1991), Partitioning of platinum-group elements in the Fe-Ni-S system and their fractionation in nature, Geochim. Cosmochim. Acta, 55, 245-253. 
Hergt J. M., B. W. Chappell, M. T. McCulloch, I. Mc Dougall and A. R. Chivas (1989), Geochemical and Isotopic Constraints on the Origin of the Jurassic Dolerites of Tasmania, J. Petrol., 30, 841-883.

Maier W. D., S.-J. Barnes and J. S. Marsh (2003), The concentrations of the noble metals in Southern African flood-type basalts and MORB: implications for petrogenesis and magmatic sulphide exploration, Contrib. Mineral. Petrol., 146, 44-61.

Momme P., N. Oskarsson and R. R. Keays (2003), Platinum-group elements in the Icelandic rift system: melting processes and mantle sources beneath Iceland, Chem. Geol., 196, 209-234.

Momme P., C. Tegner, C. K. Brooks and R. R. Keays (2002), The behaviour of platinum-group elements in basalts from the East Greenland rifted margin, Contrib. Mineral. Petrol., 143, 133-153.

Oberthuer T., T. W. Weiser and L. Gast (2003), Geochemistry and mineralogy of platinum-group elements at Hartley Platinum Mine, Zimbabwe. Part 2. Supergene redistribution in the oxidized Main Sulfide Zone of the Great Dyke, and alluvial platinum-group minerals, Mineral. Deposita, 38, 344-355.

Philipp H., J. D. Eckhardt and H. Puchelt (2001), Platinum-Group Elements (PGE) in Basalts of the Seaward-Dipping Reflector Sequences, SE Greenland Coast, J. Petrol., 42, 407-432.

Rehkaemper M., A. N. Halliday, J. G. Fitton, D.-C. Lee, M. Wieneke and N. T. Arndt (1999), Ir, Ru, Pt and Pd in basalts and komatiites: New constraints for the geochemical behavior of the platinum-group elements in the mantle, Geochim. Cosmochim. Acta, 63, 3915-3934.

Wood S. (2002), The Aqueous Geochemistry of the Platinum-Group Elements with Applications to Ore Deposits, in The Geology, Geochemistry, Mineralogy and Mineral Beneficiation of Platinum-Group Elements, edited by L. J. Cabri, pp. 211-249, Geological Society of Canadian Institute of Mining, Metallurgy and Petroleum, Spec. Vol. 54. 